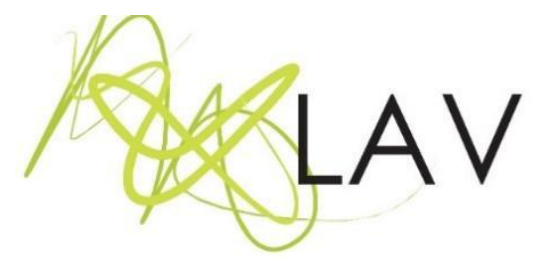

\title{
Hebe de Carvalho: educando os arte/educadores
}

Hebe de Carvalho: teaching art/educators

Ana Mae Barbosa ${ }^{1 i}$

Universidade de São Paulo

\section{Resumo}

Este ensaio faz parte de uma pesquisa mais ampla sobre Mulheres Arte Educadoras na década de 60 em Recife, Brasília e São Paulo. A intenção era buscar as marcas impressas deixadas por essas mulheres como artigos escritos por elas ou sobre elas, dissertações, teses, entrevistas, relatos, aulas, etc. Hebe de Carvalho se revela, através de entrevista que deu a Carlos Triguis para sua dissertação de mestrado. Hebe foi professora nas mais arrojadas experiências culturais e educacionais de São Paulo como o Museu de Arte de São Paulo (MASP), a Fundação Armando Alvares Penteado (FAAP), o Ginásio Pluricurricular Experimental da Lapa e a Escola Livre de Artes Plásticas do Juqueri.

Palavras-chave: arte/educação. história, reconhecimento do trabalho da mulher.

\begin{abstract}
This essay is part of a wider research on Women Art Educators in the 1960s in Recife, Brasília and São Paulo. The intention was to look for the printed marks left by these women as articles written by them or about them, dissertations, theses, interviews, notes for lessons, etc. Hebe de Carvalho reveals herself through an interview she gave to Carlos Triguis for his master's dissertation. Hebe participated as Art teacher in the most important cultural and educational experiences in São Paulo, such as the São Paulo Museum of Art (MASP), the Armando Alvares Penteado Foundation (FAAP), the Lapa Experimental Gymnasium and the Juqueri Free School of Visual Arts.
\end{abstract}

Keywords: art education, history, women recognition.

\footnotetext{
${ }^{1}$ Estou pesquisando e escrevendo, junto com alguns colegas, um livro sobre Mulheres Arte/Educadoras na década de 60. Hoje já é difícil encontrar na internet textos e imagens sobre estas valiosas artes/educadoras. As pesquisas sobre elas também são raras. Muitas estão esquecidas pela história.
} 


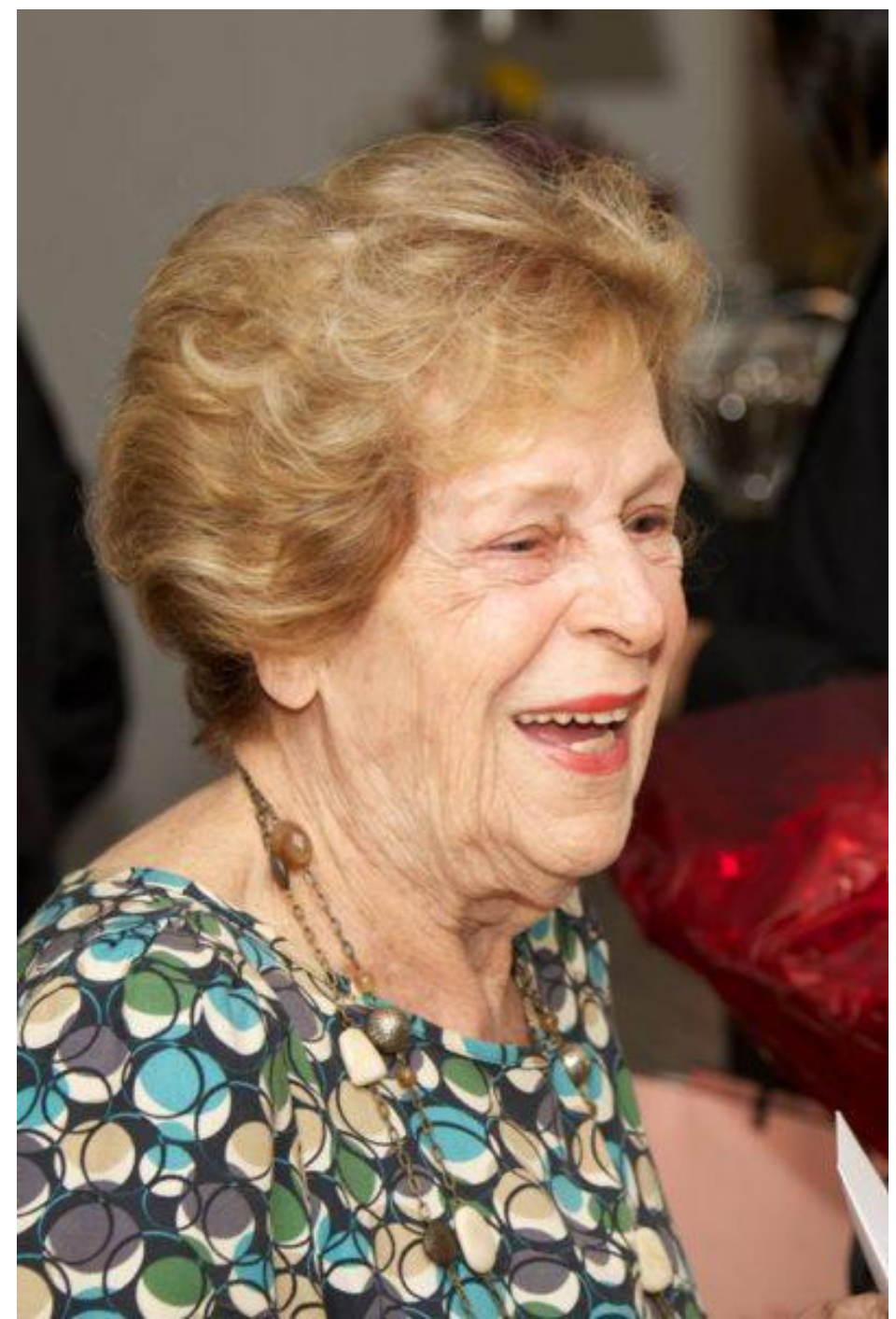

Figura 01. Hebe de Carvalho em seu aniversário de 99 anos. Créditos: Marcos Nardon sobrinho de Hebe de Carvalho

Fonte: Catraca Livre

Carlos Ernesto Triguis, em 2007 defendeu sua dissertação de Mestrado no Instituto de Artes da UNESP de São Paulo, intitulada De educando a arte-educador; influência dos mestres. ${ }^{2}$ Foi orientado por Rejane Galvão Coutinho. Conheci-o ainda durante a pesquisa

\footnotetext{
2 TRIGUIS, Carlos Ernesto. De educando a arte-educador; influência dos mestres. Dissertação de Mestrado. Instituto de Artes/UNESP, 2007.2v. Orientadora Profa. Dra. Rejane Galvão Coutinho. Disponível em: <https://repositorio.unesp.br/bitstream/handle/11449/90994/triguis_ce_me_ia.pdf?sequence=1>. Resumo: A dissertação relata e analisa uma História de Vida e Formação, mais especificamente da minha formação artística, num percurso que passa pelo extinto Grupo Escolar Experimental da Lapa, como pano de fundo da descoberta de meus valores educacionais e o encontro com àquela que plantou os alicerces para a construção desse caminho: a Professora Hebe de Carvalho. Apresento também algumas dificuldades e desvios realizados nesse percurso para conseguir os meus objetivos: a busca de minha própria expressão até tornar-me um ArteEducador. No percurso relato e analiso meus encontros com Ana Maria Netto Nogueira, Carlos Alberto Fajardo e Iole Di Natale, assim como minhas passagens pelos Festivais de Inverno da Universidade Federal de Minas Gerais. O encontro com as ideias de Ubirajara Ribeiro é também relatado, principalmente as reflexões desencadeadas pelo episódio Glorinha de Taubaté. A ideia é que esse trabalho possa despertar em outros
} 
e tive a alegria de ser convidada para um jantar que ele promoveu com amigos e ex-alunos de Hebe de Carvalho, principal personagem da sua dissertação, a mestra mais querida e celebrada por ele que analisa o trabalho de cinco de seus ex-professores. O primeiro volume da Dissertação tem 256 páginas das quais dedica 78 (19 a 98) para falar de Hebe de Carvalho (1914-2015), o contexto da escola e sua relação com ela depois de deixar a escola. No segundo volume (anexos), de 129 páginas, há quatro entrevistas sobre Hebe de Carvalho e uma com ela que perfazem 59 páginas.

Transcrevo aqui, na integra, a entrevista de Carlos Triguis com Hebe de Carvalho, sem mudar nenhuma palavra, em respeito à seriedade deste homem que foi um educador extremamente consciente acerca dos modos pelos quais aprendeu e de enorme dedicação ao como ensinar Arte. Quando há uns 8 anos comecei a pensar numa pesquisa sobre mulheres na Arte/Educação na década de 60 falei com ele e pedi a entrevista com a Hebe Carvalho. Minha ideia era, escolhidas as mulheres sobre as quais queria pesquisar, verificar o que haviam escrito sobre elas. Encontrei pouca coisa escrita, mas já conhecia a dissertação de Triguis. Ele me deu uma cópia de presente. Passaram-se os anos e só em 2017 voltei a pegar duro na pesquisa. Escrevi um e-mail a Carlos. Ele me contou que estava doente, mas que ia preparar uma introdução à entrevista. Agora em janeiro de 2018, estimulada por Vitoria Amaral, tive um surto de trator e resolvi voltar à pesquisa de Mulheres na Arte Educação no Brasil dos anos 60 com medo de morrer e não ter feito tudo que quis. Sinto-me em dívida com minhas antecessoras e com minhas contemporâneas que atuaram, principalmente, em um período no qual a internet não havia se constituído na nossa memória dominante. Sinto-me mal quando alguém afirma que sou pioneira da Arte/Educação no Brasil. Muitas outras mulheres extraordinárias me antecederam. Se quiserem me dar algum pioneirismo eu aceito no que se refere a Pós-Graduação. Sim, iniciei a primeira linha de pesquisa em direção ao Mestrado e Doutorado em Ensino/Aprendizagem da Arte no Brasil, na ECA/USP. Por anos foi a única Pós-Graduação a formar Doutores e Mestres em Arte/Educação e alimentou as Pós-Graduações que foram se constituindo, principalmente, nas Universidades Federais.

Escrevi de novo para Carlos no final de 2017. Sua mulher, Regina Célia Mobarah, a quem ele dedicou sua dissertação, me respondeu com um e-mail de uma sensibilidade comovente me contando que ele morrera, mas que havia pedido a ela para dar permissão para eu usar o que quisesse de sua dissertação. Sinto enorme responsabilidade, vou tentar dar o melhor de mim procurando sumarizar o texto sobre Hebe Carvalho um pouco 
engasgada por minha admiração por D. Hebe e por Carlos Triguis como professores e pela enorme generosidade dos dois.

Carlos nos conta que seu contato com Hebe, como professora, começou no Experimental da Lapa Edmundo Soares onde ela foi a primeira professora de Artes Plásticas em 1962. Posteriormente, em 1967, a instituição mudou de nome para Ginásios Pluricurriculares Experimentais. A década de 50 até 1964 foi muito rica em experimentação educacional, pois o MEC legalmente permitiu e estimulou a experimentação.

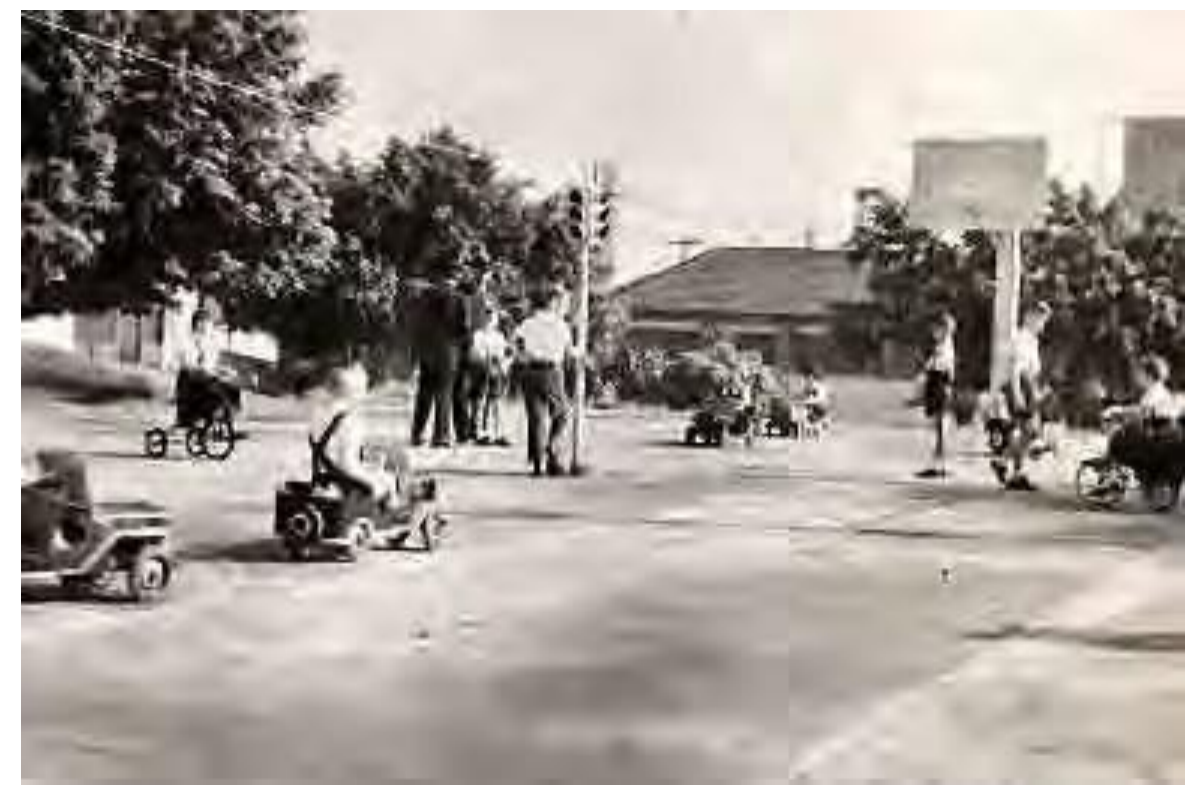

Figura 02. Aula de Trânsito no Experimental da Lapa Edmundo Soares Fonte: Dissertação de Carlos Ernesto Triguis, IA/UNESP (2007)

Diz Triguis sobre Hebe Carvalho:

Dona Hebe nasceu em Recife - Pernambuco em 1914. Pai engenheiro (...). Aqui ele se tornou especialista em arquitetura religiosa, construindo igrejas de vários estilos diferentes. Fez por exemplo a Igreja Nossa Senhora do Brasil e a Capela da Pontifícia Universidade Católica, entre outras. Ele trabalhou com Ramos de Azevedo, e com ele na Estação Sorocabana, no bairro da Luz, hoje transformada na Sala São Paulo, os detalhes, as rosáceas, as colunas foram projetos dele (TRIGUIS, 2007, p. 63).

Lembra ainda que a mãe de Hebe era professora, assim como todas as mulheres de sua família, também eram professoras. Hebe fez o Curso Normal. Casada com Pedro Xisto, 
teve quatro filhos. Duas filhas são Arte/Educadoras muito influentes: Lia Robato e Maria Amélia, a Memélia, que eu conheci na minha primeira viagem de estudos para o exterior.

O Ministério de Relações Exteriores do Brasil ofereceu bolsas à Escolinha de Arte do Brasil para professores de Arte irem conhecer o movimento de Educação pela Arte na Argentina. Naquela época estavam muito mais avançados do que no Brasil. Noemia Varela ficou encarregada de escolher os bolsistas que terminaram sendo: Alice Soares e Ligia Dexheimer de Porto Alegre; Aparecida Pallu e Maria Amélia Carvalho de São Paulo, e do Recife, meu marido João Alexandre Barbosa. D. Noemia me telefonou perguntando que facilidade eu teria de viajar sozinha. Fui sincera e respondi que nenhuma. Ela então me perguntou se eu teria dinheiro para pagar minha passagem. Diante de minha afirmativa ela esboçou o plano. Meu marido, da área de Literatura, seria o bolsista e eu iria com ele. Neste momento aprendi com D. Noemia que nós mulheres precisamos ajudar umas às outras, embora muitas vezes seja necessário criar estratégias que parecem de submissão e obediência ao poder masculino, mas que corroem este poder muito lentamente. Ainda acho que é melhor que nada.

O resultado é que o adido Cultural do Brasil na Argentina era um literato muito inteligente.

Deu-se muito bem com meu marido, que só ia aos encontros oficiais; mas aos workshops, às visitas a escolas eu ia sozinha com as outras Arte/Educadoras. Em compensação, meu marido deu conferências e um curso sobre o Modernismo Literário no Brasil a convite do adido cultural, que resolveu me dar uma bolsa pois quem estava cumprindo o convênio em Arte/Educação era eu.

Conto esta história para que as leitoras entendam o contexto da época, o patriarcalismo que precisávamos vencer, as artimanhas que usávamos e que hoje parecem desprezíveis e censuráveis. Era ingenuidade e concessão em prol da sobrevivência intelectual.

Maria Amélia, filha de D. Hebe, era ótima companheira, a mais cosmopolita de todas nós, completamente apaixonada pelo Teatro de Bonecos que se fazia na Argentina. Sua irmã Lia Robato foi uma das pioneiras da Dança no ensino Universitário na Bahia. Pedro Xisto, o marido de Hebe de Carvalho, era poeta ligado ao grupo Concretista de São Paulo. Conviver com ele, artista de vanguarda, deve ter sido estimulante para Hebe de Carvalho, que estudara de 12 aos 18 anos com Theodoro Braga. Ele era colega de seu pai, nessa época, Professor na Escola de Belas Artes de São Paulo, onde Theodoro Braga era diretor. Diz Hebe:

Revista Digital do LAV - Santa Maria - vol. 11, n. 2, p. 309 - 341 - mai./ago. 2018 ISSN 1983 - 7348 http://dx.doi.org/10.5902/1983734832833512 
Ele mandava viu! Desenhe em casa, mas ele não fazia isso com a gente, não tinha o exemplo, e depois ele era muito tradicional, ele censurava muito a pintura moderna, era um professor muito acadêmico.

Meu pai também era acadêmico. Então eu fui criada num ambiente tradicional. Só quando me casei com vinte e dois anos, foi que eu comecei a ter os olhos abertos para a Pintura Moderna (TRIGUIS, 2007, p. 65).

Ela foi trabalhar no Mackenzie dando aulas de arte para crianças de 8 a 11 anos. A professora anterior desenhava na lousa para os alunos copiarem, ela dava desenho de observação. Em 1954 Susana Rodrigues quis deixar o MASP e Hebe a substituiu. Depreendendo do que ela disse a Carlos, foi ali que começou a ser muito feliz no trabalho:

Ela (Susana) quis deixar o Museu e me chamou para substituí-la, eu comecei a trabalhar lá com crianças nesse regime de liberdade total, inclusive o trabalho era um pouco dispersivo, porque não era uma sala só para essa finalidade, então o material tinha que ser levado para a cada vez, os trabalhos das crianças não eram guardados porque não tinham pastas, ficava um trabalho meio caótico, sabe quando conseguimos um lugar melhor? Foi quando o Museu (1955) se fundiu com a Fundação Armando Álvares Penteado - FAAP e passou para o Pacaembu (TRIGUIS, 2007, p. 67).

As aulas para o curso infantil na FAAP começaram repetindo o horário do Clubinho Infantil de Arte do MASP aos sábados, à tarde passando posteriormente para as manhãs. Depois foi havendo procura para aulas durante a semana, e aí foram abertas aulas duas vezes por semana.

Na entrevista a Trigues, ela citou ter lido Viktor Lowenfeld, Herbert Read, Arno Stern e Franz Cizek, cujo livro encontrou uma vez, em português na Michelangelo. ${ }^{3}$ Era o que havia para ler na época. Fomos conhecer os livros de Arnheim na Argentina.

Em 1965 [...] D. Hebe deixa o Experimental e a FAAP para abrir a sua própria escola. O Ateliê de Arte Infantil, inicialmente na Avenida Paulista, num conjunto comercial, todo envidraçado com uma bela vista (TRIGUES, 2007, p. 77).

Foi onde a conheci em 1967 quando me asilei em São Paulo, depois de ser demitida da Universidade de Brasília por razões políticas (1965). Visitei as colegas da área antes de abrir a Escolinha de Arte de São Paulo. D. Hebe foi de especial ajuda dando endereços onde comprar mais barato papel, pincéis, instrumentos de gravura, etc.

\footnotetext{
${ }^{3}$ Deve ter sido editado em Portugal. Nunca soube desta tradução. 
Triguis fez excelentes e longas entrevistas com dois ex-alunos de Hebe Carvalho4: Célio Bernardes, considerado "terrível", por D. Hebe e seus auxiliares, e Paula Motta, filha de Flavio Motta, diretor dos Cursos da FAAP, ex-aluna na FAAP durante oito anos, e posteriormente colaboradora no Ateliê de Arte Infantil. Essa em seu depoimento ao autor da dissertação em fevereiro de 2006, assim se expressa comparando o trabalho de Hebe Carvalho com o de Fanny Abramovitch, onde estagiou ao mesmo tempo em que ensinava junto com Hebe Carvalho.

O ambiente lá na Escola da Fanny era bem diferente. Primeiro tinham várias atividades simultâneas, era nas concepções atuais um ambiente mais multimídia, mais voltado para o teatro, com muitos jogos dramáticos, e a orientação era deixar a criança fazer o que quisesse, o que valia para ela era o processo, não o produto. D. Hebe valorizava o produto, ela achava importante o resultado e que a criança concluísse alguma coisa por si própria.

$\mathrm{Na}$ verdade, acredito que ela deixava a questão do resultado não como demonstração para os pais, mas, para a criança refletir sobre sua própria realização. Por isso quando ela sugeria alguma coisa era sempre muito sutil, chegando a resultados determinados.

E, na época, lá na Fanny, a coisa era assim um 'oba-oba' de experimentação.

De repente, havia crianças que passavam a tarde, derretendo giz de cera para brincar com fogo, por exemplo. Ele não ia fazer encáustica, ou alguma coisa assim.

E trabalhava muito com sucata. $\mathrm{Na} \mathrm{D}$. Hebe éramos muito criteriosos na colocação e uso da sucata (TRIGUIS, 2007, p. 78).

Triguis conclui: "Explicando seus métodos, D. Hebe diz que procurava eliminar práticas muito utilizadas na época, que ela considerava pouco criativas, tais como: simples preenchimento de espaços, uso de fórmulas abstratas bonitas, mas convencionais, e que não faziam parte do universo infantil. D. Hebe dizia que a criança compreende e trabalha com o figurativo, o abstrato só vai começar a fazer sentido um pouco mais tarde.

Ela exigia um pouco a utilização correta da técnica, dependendo da possibilidade da criança, sempre visando certo desenvolvimento técnico para que ela pudesse através dele se aprimorar, expressando-se melhor. Quanto a forma da criança criar, era totalmente

\footnotetext{
${ }^{4}$ Sobre Hebe Carvalho, Triguis entrevistou Maria Amélia Carvalho, Malvina Nogueira, Paula Motta, Célio Bernardes de Andrade e com referência ao Experimental da Lapa ao tempo de Hebe Carvalho entrevistou José Fusari. Ao todo fez 20 entrevistas sobre os educadores que constituíram o tema de sua dissertação.
} 
livre, mesmo quando se colocava um modelo para que a criança trabalhasse (TRIGUIS, 2007, p.74).

Passo a publicar na íntegra a entrevista de Hebe Carvalho ao seu ex-aluno e Arte/Educador, Carlos Ernesto Triguis:

\section{Entrevista com a professora Hebe de Carvalho}

DATA: 21.08 .2005

LOCAL: Residência de Maria Amélia de Carvalho

HORÁRIO: $16 \mathrm{~h}$ às $20 \mathrm{~h}$.

CE - CARLOS ERNESTO

HC - HEBE DE CARVALHO

CE - Eu vou começar perguntando para a senhora, a senhora é de Pernambuco, não é?

HC - Por acaso. Não, não foi por acaso. Meu pai foi morar lá, trabalhando no saneamento, ele era recém-formado como Engenheiro Arquiteto, mas o emprego que ele achou foi de engenheiro, nessa Comissão de Saneamento; ele trabalhou primeiro no saneamento de Santos; fez aqui em São Paulo o Jardim América todinho, que era um charco, e depois foi fazer o saneamento de Recife. Aí ele conheceu minha mãe lá, ela era professora; a família todinha de minha mãe era de professoras mulheres; eram muito inteligentes e ele se casou com a minha mãe. Morou lá dois anos, depois de dois anos vieram embora para São Paulo, pois ele havia terminado o serviço lá. E eu vim com essa idade, com um ano e pouco, para São Paulo; nunca mais saí daqui. Somente agora, há oito anos, eu estou morando em Salvador, na Bahia. Considero-me muito paulista, às vezes até esqueço que sou de Pernambuco, porque eu vivi a minha vida toda aqui em São Paulo. Agora, com muita convivência com os pernambucanos, depois fui casada com um homem pernambucano.

CE - Conte-me uma coisa, a senhora foi aluna do Theodoro Braga, como era o Theodoro, como foi essa convivência, o que ele passava o que a senhora acha que ele passou?

HC - Olhe, Theodoro Braga era muito boa pessoa, tranquilo, muito estudioso e ele era apaixonado por História do Brasil. Ele fez muitos quadros sobre bandeirantes, sobre a história de São Paulo.

CE - Com quantos anos a senhora estava quando começou a estudar com ele? 
HC - Doze.

CE - Doze!

HC - Ele era colega de meu pai, meu pai era professor nessa época, na Escola de Belas Artes, aqui em São Paulo. E o Theodoro Braga nessa ocasião, era o diretor da Escola de Belas Artes. Eles foram a Campinas num grupo de educadores com o Secretário da Educação e me convidaram para visitar a Escola Normal de Campinas que era ali no Largo Carlos Gomes. E eu estava morando durante um ano lá em Campinas. A minha mãe tinha ido a Recife visitar a família dela; nós éramos sete filhos, ela levou quatro e deixou com o meu avô em Campinas. E a minha tia, nessa ocasião, era diretora da Escola Normal de Campinas, e tinha o Grupo Escolar, eu estava já no quarto ano, que na época ia até o quarto ano, a quarta série; como se chamava a quarta série?

CE - Quarto ano primário.

HC - E a minha professora ela era apaixonada por pintura. Então ela dava para os alunos papel e pastel verdadeiro mesmo para trabalhar. E ela não dava, como se usava naquela época uma imagem já pronta para a criança copiar. Ela colocava, ela fazia uma natureza morta natural, colocava na frente, e todos as alunas copiavam. E o Theodoro Braga olhou o meu trabalho e gostou muito. Então ele disse ao meu pai: "- Olha essa menina precisa estudar! " Eu ia fazer doze anos. Quando eu completei doze anos, eu terminei o curso lá, e vim para São Paulo. Então meu pai me colocou no ateliê dele, que tinha adultos à noite. E eu tinha aulas das sete as nove, e era na Avenida São João, quase esquina da avenida Ipiranga, creio que ainda existe o edifício até hoje lá. E ele era casado com uma alemã, uma senhora gorda, inteligente, e era apaixonada por ele, e ela dizia ele me chama de "Meu Amor"; os dois eram muito unidos, era muito agradável lá, a convivência com ele era uma delícia, ainda mais que eu era a caçula da turma, e ele achava que eu tinha muita facilidade para copiar, e gostava muito do meu traço que era super delicado, ele tinha um traço leve, ele gostava muito. Ela me endeusava, ele me achava um verdadeiro talento, eu copiava com muita fidelidade. Eu fazia retratos muito fiéis, fazia retratos muito bem resolvidos. Eu começava daquela forma tradicional, primeiro você fazia gesso, alto-relevo, não se fazia terceira dimensão, primeiro eram chapas de gesso ou de papelão com folhas de Arkansas e aí você desenhava e modelava o claro-escuro, você ficava meses naquilo; daquilo você passava para as figuras de gesso em terceira dimensão, e usam em geral figuras de guerreiros, que se compravam prontos na Michelangelo, ali numa ladeira em frente ao Banespa no viaduto do chá. Então ali a gente comprava mão, comprava pé, comprava braço, e a gente ia copiando, copiando aquela montagem toda, isso durante um

Revista Digital do LAV - Santa Maria - vol. 11, n. 2, p. 309 - 341 - mai./ago. 2018 ISSN 1983 - 7348 http://dx.doi.org/10.5902/1983734832833512 
ano inteiro. Eram aulas duas vezes por semana, duas horas. Depois disso, foram dois anos de estudo de desenho, passávamos para a figura humana: então, era figura humana do natural, modelos e eu levava meus irmãos para posar. Eu tinha muitos irmãos. Eles pousavam de sunguinha, de maiô para gente poder ver a natureza do corpo. Era tudo meninada, tudo criançada. Figura humana de mulher, eu nunca pintei. Porque eles não alugavam modelos. Então para não gastar com modelo vivo, eles levavam só criançada, ou então outras pessoas que iam para pousar, amigas. Então, a gente fazia muito rosto e eu virei retratista, porque eu gostava de fazer aquilo à força. Eu virei retratista, de tanto desenhar. Porque eu fiquei lá até os dezoito anos. Aí eu passei a trabalhar com óleo, aquarela, mas raramente nós saíamos do ateliê. Nós só fazíamos natureza morta, e não tínhamos um trabalho de criatividade, porque ele mandava a gente fazer nuns tons, e eu não tinha o hábito de fazer isso desde menina, eu fiquei muito amarrada à figura. Por isso que depois, quando eu comecei a ensinar, parti para outro estilo. Vamos primeiro desenvolver a criatividade. Ele mandava viu? Desenhe em casa, faça em casa, mas ele não fazia isso com a gente, não tinha o exemplo, e depois ele era muito tradicional, ele censurava muito a pintura moderna, era um professor muito acadêmico. Eram judeus, que estavam por trás, incentivando toda a arte moderna, e meu pai também era acadêmico. Então eu fui criada num ambiente muito tradicional. Só quando eu me casei, com vinte e dois anos, fiquei noiva quatro anos, então com o meu ex-marido, foi que eu comecei a ter os olhos abertos para a Pintura Moderna. Fiquei encantada; então, abandonei o Theodoro Braga, porque ele também tinha abandonado as aulas nessa época, e enfim eu comecei a frequentar e só gostar da Pintura Moderna, mas não era ainda a pintura abstrata. Os Modernos maiores eram a Tarsila, era Segall, Anita já nessa época não era tão moderna. Isso foi mais ou menos em 36, 38, a Anita já tinha decaído. E ela foi muito Moderna e muito atual no começo, na década de vinte, não é? Ela tinha vindo da Alemanha e estava com a influência direta da Bauhaus, ela diretamente com os expressionistas alemães, então ela fez aqui uma pintura muito marcada pelo expressionismo alemão.

CE - Uma curiosidade minha. Eu sempre achei que a Anita nunca se levantou totalmente daquela crítica do Monteiro Lobato.

HC - Eu acho que isso é um pouco de fantasia, se repete muito isso, não é? Ele não tinha conhecimento dos artistas europeus, e vendo de repente aquela mulher com aquela instrução moderna... Parece-me que ela se ressentiu bastante com isso, porque senão ninguém falaria tanto nisso, mas para mim os pintores vanguardistas alemães, ela foi estudar lá, ela tinha um defeito congênito e lá, ela teve oportunidade de estudar, e depois ela chegou aqui num meio que não tinha contato com eles, e ela foi se acomodando para agradar o público daqui. Ela naturalmente precisava ganhar a vida. E a pintura dela perdeu 
a cor. Eu acredito mais nisso do que propriamente ela tenha ficado tão traumatizada. Eu acho que aquilo foi mais uma coisa que se jogou e pegou.

CE - Agora, a senhora foi aluna do Nelson Nóbrega também. E ele não introduziu a senhora no Modernismo?

HC - Você sabe que eu fui aluna dele na Escola Caetano de Campos. No curso complementar. Era um curso intermediário, entre o curso primário e o curso normal. Três anos de curso. Então o curso dele aí era absolutamente inócuo. Eu não aproveitei nada. Ele não conversava com os alunos, ele mandava a gente desenhar, eu não sei mais o que. Eu acho que era modelo vivo. Ele era muito jovem. Ele era mocinho, devia ter uns vinte e dois anos, quando entrou como professor.

CE - Mas depois a senhora trabalhou junto com ele na FAAP, não é?

HC - Mas aí ele já era um grande professor de pintura. Muito bom professor, nessa época. Mas naquela época, ele não tinha condições. Mas não tinha condições também. É como você diz, o que é que se pode fazer, numa carteirinha pequena, numa sala de aula, sem ter material, sem ter ambiente, sem ter mesas próprias, material que você possa desenvolver conversas com os alunos. Pega uma classe de quarenta alunos para em uma hora ter que desenvolver algum trabalho, o que é que você pode fazer?

CE - D. Hebe, como é que apareceu essa vontade na senhora de ensinar, ou foi um convite, como é que foi? Como começou essa experiência como professora?

HC - Começou que eu pintava e um pintor quando ele não vende o seu trabalho, e precisa ganhar um dinheiro, ele vai ser professor. Porque é um mercado que está sempre aberto. Ou você entra numa escola para ensinar. Ou você põe alunos na sua própria casa. Eu fiz as duas coisas, então eu preparava, dava aulas para adultos, mesmo em casa, eu ainda estava casada. Quando eu me desquitei, eu estava com 36 anos, eu tive necessidade mesmo de ganhar dinheiro, foi aí então que eu comecei a procurar escola, para trabalhar. Então fui trabalhar no Mackenzie, fui trabalhar na Graded Schooll, mas sempre aquele ensino tradicional, de trabalhar numa carteira, no máximo lápis preto ou lápis de cor, e modele que a gente colocava para a criança e procurava adestrar a criança para copiar o desenho. E eu nunca tinha estudado ensino de arte para criança, a Educação através da Arte, que era uma matéria muito recente, não se ouvia falar nisso; quando se começou a falar mais da Educação através da Arte, foi nos anos 40. Então eu desquitei em 1950, aí é que eu precisei trabalhar mais, foi quando a Suzana Rodrigues me convidou para trabalhar no Museu. Mas, acho que não foi 1958 não. Eu acho que foi 1956. 
CE - A senhora também, e o professor Flávio Motta falou-me também, que a senhora fez parte do Grupo Santa Helena, ou a senhora era muito amiga deles, frequentava o ateliê deles, como era isso? Como foi essa experiência? A senhora fazia parte do grupo?

HC - Não, eu não era do grupo. Era porque eu era casada, eu levava uma vida muito doméstica, eu tinha filhos, eu tinha que cuidar das crianças. Quer dizer, eu não tinha que cuidar, eu tinha empregada, mas eu gostava de cuidar, eu gostava mesmo de cuidar das crianças, de passear com eles de estar junto, de conversar. Enfim, eu queria dedicar muito tempo a eles, e ficava. Fazia muitos retratos, tinha muitas encomendas de retratos, mas era uma coisa irregular, não é? Bom, nessa época de 1950, mais ou menos, eu conheci a Alice Brill. Alice Brill deixa-me ver em que ano eu conheci a Alice. Foi em 1949, mas ela fez uma exposição na Galeria Prestes Maia, ali na Praça Patriarca. Ela fez uma exposição do pai, que tinha falecido há pouco tempo, e ficamos muito amigas. Então, eu conheci artistas que eram muito amigos dela como Guersoni, por exemplo, que era amigo dela e outras pessoas do Grupo Santa Helena como Rebolo, Zanini, Galvez, Paulo Rossi Ozir; enfim, aí eu comecei a ter contato com essas pessoas, e a ver as exposições deles, e as exposições do Sindicato dos Artistas Plásticos. E eles me convidaram para começar a participar; minha pintura começou a ficar mais solta, eu comecei a ver mais as pinturas, a estudar mais, através dos livros, estudar Guignard, a estudar Segall, Tarsila, e aí eu comecei a soltar mais a minha pintura, uma pintura mais livre e pegando assuntos mais variados do que só retratos, retratos. Eu fazia retratos aí como uma maneira de reforçar o orçamento, porque nessa época eu separei então nessa época eu precisava mais ainda de dinheiro. O meu marido logo viajou desde essa época ele viajou muito, ele passou muitos anos fora do Brasil. Eu tinha uma pensão, ele dava, mas houve uma inflação muito grande, aqui, então o dinheiro com que eu tinha ficado quando eu me separei, não dava mais para a renda doméstica. Então eu precisava cada vez mais trabalhar, mas eu só sabia ensinar, então eu fui ensinar neste colégio, depois eu fui ensinar na Fundação do Museu de Arte, passou depois para a Fundação Armando Álvares Penteado, fiquei trabalhando na Fundação, ganhando muito pouco, mas dava junto com a mesada que o meu marido mandava.

CE - D. Hebe, no Museu e na Fundação a senhora seguia um método, ou a senhora tinha alguma coisa sua para dar aulas?

HC - Bom, quando eu comecei a ver aquela quantidade de material, eu não sabia lidar com aqueles materiais. E ao mesmo tempo eu fui percebendo que eu precisava dar bastante material, porque com os anos, os alunos iam ficando de um ano para outro, eu tive alunos que começaram comigo com cinco anos de idade, e saíam depois com doze

Revista Digital do LAV - Santa Maria - vol. 11, n. 2, p. 309 - 341 - mai./ago. 2018 ISSN 1983 - 7348 http://dx.doi.org/10.5902/1983734832833512 
anos de idade, quando eu já tinha saído da Fundação e aberto minha escola. Então, eu precisava a cada dia criar o maior número de técnicas, para que o aluno se interessasse; porque não estava ainda na idade do aluno criar por si as coisas, ele ia criando através do material, eu acredito muito nisso, que o material influi na criatividade. Então, eu não queria deixar o aluno, numa só maneira dele trabalhar. Então, eu precisava dar técnicas diferentes, cada técnica se expressava de uma maneira, por exemplo, eu dava muito linóleo, porque o linóleo leva a uma simplificação obrigatoriamente. Ou então, técnicas de acaso, técnicas de acaso obriga as pessoas a se afirmar, porque toda a classe faz um trabalho mais ou menos igual, então eu sempre procurei muito fazer o desenho, e formar, fazer com que a criança trabalhasse bem esse desenho, essa gravura, vamos supor, mas que ela realizasse o melhor possível. Para realizar o melhor possível figuras e fundos. Para ela ficar segura, ela precisava não se sentir influenciada com relação ao colega; então você tem que, uma vez por semana, dar algum trabalho que seja de acaso, que a classe inteira faça igual, que fiquem todos no mesmo nível, porque a criança tem um olho crítico muito grande, ela mesma sabe, quando ela faz um trabalho bom ou, quando ela faz um trabalho inferior. Então, é preciso que você não deixe que um aluno sobrepuje muito ao outro. Então, que todos tenham realizações boas, bem que não seja sempre e não valorizar absolutamente nenhum trabalho. Eu nunca elogiei na classe, um trabalho de algum aluno mais do que de outro. Tanto que quando eu entrei no Grupo Escolar Experimental, eu mandava pedir a um aluno para fazer uma ilustração qualquer que eu precisava na sala, fora da hora da aula. Às vezes eu precisava de algum trabalho de um aluno e mandava buscar, então a professora dizia: - Oh, fulano esse é o que desenha bem, fulano vai você. E eu dizia: - Eu quero um aluno comum. Não me mande um aluno bom, o melhor desenhista, então no fim, quando eu mandava buscar, eu pegava qualquer um. Para não ser sempre um, que era o bom. Porque, os outros todos se sentiam mal, não queriam concorrer com aquele que era o melhor.

CE - E como a senhora conheceu D. Therezinha Fram e como foi o convite para a senhora ir para o Experimental?

HC - Não me lembro, mas eu acredito que ela foi me procurar na Fundação, ela soube que eu trabalhava na Fundação porque eu nunca corri atrás de trabalho! Eu não tinha tempo para correr atrás de trabalho, eu tinha que cuidar da minha casa. Eu fazia as minhas encomendas, eu ainda ensinava na Fundação. Porque a Fundação quando eu fui trabalhar lá, nós começamos com uma aula por semana, com vinte alunos, quando eu deixei a Fundação, em 1965, no final de 65, nós tínhamos trezentos e tantos alunos, com seis ou sete professores. Eram muitos alunos e professores. Então, eu não tinha tempo de correr atrás, só uma vez, uns três anos antes, eu cheguei ao Bardi, quando ele ainda era diretor, 
quando ele ainda estava na FAAP, que eu cheguei a ele e falei que precisava ganhar mais dinheiro. O que eu estou ganhando aqui não está dando. Nós ainda não tínhamos tantas aulas porque nós não abrimos um curso para a $A A C D$, por exemplo. E a gente pode incorporar mais alunos da $A A C D$, no momento era um médico muito famoso que fazia um movimento social muito grande que já tinha procurado o Bardi, que tinha uma ligação com ele, pois então, isso foi a única vez que eu procurei trabalho lá, dentro mesmo de onde eu trabalhava, eu queria um número maior de aulas, porque nessa ocasião, eu estava acumulando também aulas para adultos, mas aí a Fundação começou a crescer, e então vieram outros professores e eu fiquei só com o curso infantil. Restaram muito poucas aulas para mim. Foi quando o pessoal da $A A C D$ veio. Eles traziam peruas e traziam as crianças para lá. Mas depois ficava muito difícil, aquele tipo de crianças que não podiam andar direito, tinham um defeito físico, então, não podiam andar (interrupção da fita). Então a criança sempre desenha o sol e que dizem os psicólogos que o sol representa o pai e a água representa a mãe. Porém, eu notei uma criança que nunca desenhava o pai; eu vim, a saber, depois, que a mãe era separada do pai, e que o pai era absolutamente ausente. E essa criança nunca desenhou o sol. Por uma observação minha, entendeu? Agora, eu cheguei a observar uma criança que tinha uma ligação muito grande com o pai, ela desenhava um sol muito grande, muito importante. Porque na verdade, quando eu acompanhava, eu não tinha tempo de fazer muitas pesquisas, nem grandes estudos. $E$ eu sempre conheci pessoas muito cultas que trabalhavam muito, e que quando iam ensinar eles deixavam a desejar, porque eles não seguiram certas regras básicas, materiais para poder desenvolver a criatividade das crianças: pintura, modelagem, gravura, etc. Você tem que usar certa habilidade manual, você tem que fazer lidar com os objetos, para isso você precisa ter ambiente que dê condições de fazer. Você pode esporadicamente estando sozinho, trabalhar muito, dois metros quadrados com algum material que você cata por ali, mas você não pode fazer isso, numa sala de aula com tantas crianças, com vinte crianças que seja, você não pode, ela não vai ter condições próprias de trabalhar. Se você tiver o seu espaço mais ou menos delimitado, e o seu material, a mão e condições próprias dele trabalhar, para mim isto é o principal. Então, acho que são regras muito simples que a gente tem que ter. Você tem que ter: Saber estimular a criança, saber criar um ambiente agradável limpo e propício, com material que ele possa a recolher ali a vontade. Organização e respeito pelo trabalho que ele faz. Eu acho isso.

CE - Agora, e esse estímulo como que é? O estimular a criança como é que é? A gente pode estimular?

HC - Você pode estimular de diversas formas.

Revista Digital do LAV - Santa Maria - vol. 11, n. 2, p. 309 - 341 - mai./ago. 2018 ISSN 1983 - 7348 http://dx.doi.org/10.5902/1983734832833512 
CE - Como é que a senhora fazia?

HC - Você pode estimular cada dia. Você procura uma coisa nova, você traz uma flor diferente, você exalta aquilo; você conta uma história, você põe uma música, você conversa sobre aquela música. Você inventa uma maneira diferente de usar o papel, você não dá sempre igual. Um dia você dá maior, outro dia você dá menor. Um dia você dá uma flor amarela, outro dia você dá uma folha branca. Um dia você dá jornal, outro dia você dá recorte. Você precisa ver alguma coisa que há tempo você não dá, para não deixar muito tempo sem dar. Porque ele cria uma rotina de trabalho, mas sem monotonia; e para a criança fazer um trabalho, que daí a uma semana ele possa dar continuidade, e dele aprimorar. Mas que ele não se enfastie. Agora a pintura é sempre a preferida. A pintura a criança nunca se cansa de fazer. Agora você vai estimular para que ela recrie, mais se ela está a muito tempo sem repetir formas, você vai recriar através de uma história, de um objeto, de um pensamento, de uma atitude.

CE - Mas a senhora, por exemplo, apresentava fotos de obras de arte?

HC - Apresentava, mas eu não acho que isso seja importante isso é, mais cultura. A criança ainda não está em tempo. De um modo geral, eu levava crianças, eu apresentava, eu tinha livros de arte, a disposição das crianças. Tanto, que eu tenho livros de arte meus finíssimos, mas que estão todos marcados porque eu deixava as crianças manuseá-los. Eu acho que uma visita correndo a um Museu não leva a nada, é tão gostoso, você pode fazer isso uma vez ou outra, na tentativa dessa criança estimular-se por aquilo. Agora eu acho que esperar a maturidade da criança, que ela procure depois, você vai ensinando aos poucos, sem forçar muito, e ao mesmo tempo sem marcar porque é muita diferença entre a obra de arte, e um trabalho abstrato, ela pode achar muito parecido, apesar dele ter outras regras e ser uma coisa muito difícil, mas a má aparência tanto é que todo mundo diz: "Isso qualquer criança faz", "um quadro abstrato qualquer criança faz", mas o quadro clássico é muito difícil a criança querer imitar. Então eu não acho que se deve dar muito. Acho que isto não acrescenta nada, eu acho que acrescenta estimular a olhar a natureza, não sei, a cada criança é uma coisa, é tão difícil, e quando você pega uma classe grande, então você não pode cuidar de cada criança. Então, eu dava o material geral. Depois, quando eu percebia que aquela criança não estava interessada, quando eu podia, quando eu tinha tempo, naquele tempo de aulas, de perceber a deficiência dos meus alunos particulares, eu tinha tempo de conhecer a criança e saber o que ela gostava realmente e o que a estimulava. Então, cada um, a gente já encaminhava para aquilo, eu deixava sempre uma mesa geral de trabalho, eu deixava uma parte para a criança, uma parte separada de material, diversificado, que eu não podia dar para a classe toda. Determinados

Revista Digital do LAV - Santa Maria - vol. 11, n. 2, p. 309 - 341 - mai./ago. 2018 ISSN 1983 - 7348 http://dx.doi.org/10.5902/1983734832833512 
materiais tinham que ser com grupos pequenos de crianças, porque senão, virava balburdia e aí eu não conseguia mais trabalhar. Então eu dava sempre procurando que todos tivessem aquela experiência, que como eu conhecia muito as crianças, eu sabia quem não tinha tido determinada experiência com aquele material, mas nem sempre ao mesmo tempo. Mas, o que a gente pode dar ao mesmo tempo, é a pintura, porque a pintura você dá algumas regras, e ela depois desenvolve por si. Você dando um lugar que ela possa misturar tintas. Se eu conhecia as crianças, o trabalho de cada criança pelo colorido. Cada uma tinha o seu colorido próprio. Porque eu dava aqueles portas-ovo com doze lugares para ovos e eu colocava só as cores básicas, eu queria que as crianças elaborassem as suas cores. Eu nunca dei cores secundárias ou terciárias, dava só as cores primárias. Às vezes eu dava um lilás, que esse é muito difícil de fazer. Esse eu comprava pronto. Eu dava o ocre também. Agora, o marrom eu mandava eles fazerem com vermelho e verde. Violeta é que eles não conseguiam.

CE - Como foi essa experiência no Experimental? A senhora ficou lá dois anos? Três anos? HC - Não, cinco anos. Peguei crianças desde o primeiro ano até o quinto. Eu quis levar até o quinto ano. Foi muito difícil. Precisava ter muita energia, eu quando terminava o dia de trabalho lá, precisava ficar meia hora trancada na sala de professores, sozinha, até eu conseguir botar o pé na rua. Porque senão eu não tinha energia, porque entre cada classe, eu tinha dez minutos, para preparar o material para outra. Mas eu queria ver o que tinha - teve aula de artes, uma vez por semana, durante quatro anos, o que é que ela captou?

CE - A senhora já foi para lá com esse objetivo? Ou foi alguma coisa que surgiu depois que a senhora estava lá?

HC - Não, eu fui com a intenção de fazer uma experiência. Não sabia que eu ia poder ficar lá tanto tempo, ou não sabia se iam me contratar. Mas eu quis fazer uma experiência para ver se eu conseguia o mesmo resultado que eu obtinha com as crianças que eu lecionava e que eram crianças que os pais tinham optado por colocar lá e eram crianças que os pais tinham colocado porque tinham tendência para a pintura.

CE - Então seria uma comparação entre as crianças que a senhora tinha na FAAP com as crianças do Experimental?

HC - Na FAAP eu tinha muitas crianças filhas de outros artistas, por exemplo, o filho do Waldemar Cordeiro, do Gruber, eu tive filhos de intelectuais. Eu tinha, por exemplo, filhos de Pedro Farkas, que ficaram muitos anos lá, e tinha uma quantidade grande de pais muito interessados ou dedicados à arte. Eu achava que essas crianças eram privilegiadas, e 
trabalhariam talvez melhor do que outras, mas na verdade, o interesse que as outras crianças tinham se o grau de realização era igual. Porque lá no Experimental, nós conseguimos todo o material que eu tinha lá na Fundação, nós conseguimos lá. As crianças davam uma quantia por ano (já não sei mais que moeda era), acho que eram CR\$100,00 (cem cruzeiros), então nós comprávamos o material, todinho para o ano todo. E nós tínhamos o mesmo papel Kraft bom. Eu comprava por bobinas, bobinas enormes, por metro. Era um material bonito. Então esses papéis estimulavam muito a criança. Ela trabalhava com gosto. Por isso eu dava material, porque eu dava potes grandes de água e nós fazíamos as tintas com pó de pintor, que eu misturava com dextrina. Porque quando a gente usa outro tipo de cola, a tinta endurece, e essa tinta com dextrina, você depois põe um pouco de água e ela volta, tanto que quando as crianças usavam o porta-ovo, e elas usavam toda a tinta, então eu guardava, não lavava. Colocava depois um pouco de água ali para aproveitar aquilo, aquela tinta. E no fim dos potes, a mesma coisa, deixava no pote, mesmo que ficava lá embaixo, eu colocava um pouco de água, acrescentava mais para não perder o material. Eram pincéis Tigre, naquela ocasião, e eu dava três tamanhos: mais grosso, médio e fino. Aqueles chatos. Eu não dava pincel redondo. Então, a criança gosta muito você dando sempre isso, a criança está sempre contente. Mas tem que dar material que estimule. Então, o estímulo é feito através da palavra, através da atitude que você tem para com a criança, e através de pequenos meios. Cada professor encontra o seu caminho. Nós não podemos ter umas regras fixas, que cada professor tem as suas qualidades e as suas limitações. Você não pode dar uma regra fixa, ele tem que achar a sua maneira, se ele não achar a sua maneira de trabalhar, ele não será um bom professor. E depois dentro disso, nós temos que ver com cada aluno, como você vai lidar, para que ele produza alguma coisa. Você precisa ficar um tempo com ele. Porém, isso na Lapa, era muito difícil. Havia a diretora lá, que nunca me pediu nada, nunca me impôs nada, sempre respeitou o meu trabalho. Nunca tive com a Therezinha, uma palavra que não fosse de estímulo e de compreensão, de apoio ao trabalho. Agora, havia uma diretora que veio me cobrar. Ela veio me cobrar avaliação, e eu disse: "- Eu não tenho condições de fazer isso de quinhentas crianças. Eu vou fazer uma avaliação falsa". Eu não sei nem o nome de todas as crianças, eu sei o nome de raras crianças. Eu não tenho tempo para cuidar disso. Eu não tenho tempo para dedicar mais daquele das aulas, para a qual eu sou contratada. Para trabalhar na minha casa, eu aqui, eu tenho que distribuir o material, cuidar do material, ordenar a sala, para que eles tenham condições de trabalhar. Eu não paro um minuto e eu tenho que dar atenção a todos os alunos, mas como você pode ensinar, senão conhece nem o nome dos alunos? Como você pode dar uma orientação para os alunos? Eu observo o trabalho de cada um todas as aulas, então eu vejo aquele trabalho, no que ele está tendo deficiência, o que ele está precisando, tecnicamente. Bem, agora fazer uma

Revista Digital do LAV - Santa Maria - vol. 11, n. 2, p. 309 - 341 - mai./ago. 2018 ISSN 1983 - 7348 http://dx.doi.org/10.5902/1983734832833512 
avaliação.... Eu tenho que avaliar, fazer uma avaliação, de acordo com a própria capacidade, o que aquele aluno tem. Eu não posso comparar o trabalho de um com o outro. Não é pelo trabalho que eu vou avaliar, não. Porque isso é relativamente fácil. Eu coloco no fim da aula todos os trabalhos e vejo, pessoalmente aquele que eu acho mais bonito. Isso também é uma coisa falha, porque não é matemática. Vai depender do meu gosto, eu posso gostar do vermelho, e o aluno gostar de verde, como eu vou dizer qual é o melhor? Agora, eu posso dizer que aquele aluno está progredindo, que ele está ali fazendo maiores experiências, que ele está demorando mais no trabalho, se ele está interessado, ou se ele gosta realmente de fazer uma mancha, eu não posso fazer uma avaliação, nem posso comparar nota. Porque cada um dá o que pode. Se ele estiver dando aquilo que é o máximo dele, aquele é nota dez. Ele está dando o que ele pode. E se eu estou dando uma orientação geral para todos, teoricamente a avaliação é igual. Tem muitas coisas muito curiosas, de passagens, eu não estou conseguindo contar. Sabe de quem eu fui colega no ateliê do Theodoro Braga? Eu fui colega da Noemia Mourão, esposa do Di Cavalcanti. A Noemia Mourão era uma moça feia, magra, morena, de um busto muito grande, tinha uns óculos dessa grossura. Ela era tão míope que usava os óculos e os olhos ficavam pequeninos. Aí eu soube que ela vivia, naquela época, que ela era, uma palavra um pouco forte para a época, que ela era amante do Di Cavalcanti.

CE - Ah, mas ela não era casada com ele?

HC - Quando eu soube ela era amante. Quando me falaram, falaram assim. Então ela estava em Paris. Quando ela voltou de Paris, ela era outra pessoa. Era uma mulher linda! Engordou, tirou os óculos, botou lentes de contato, operação naquela época, não se fazia. Eu acho que já havia lentes de contato. Ela era muito elegante, muito bonita, tirou o busto, naturalmente. Ela ficou uma mulher, charmosíssima, muito charmosa, e era uma linda mulher.

HC - Um dia eu encontrei um livro do Cizek em português, eu tinha ele, mas doei para alguém, nunca mais achei. Eu comprei na Michelangelo, quando era na Líbero Badaró. Eu o comprei logo que comecei a ensinar. Comprando material, material que ensinava como fazer mão, pé, rosto, tinha o Cizek lá. Depois é que eu fui ler Lowenfeld. Todo mundo conhece a psicologia mais ou menos por alto hoje, como se deve lidar com a criança.

Fim da primeira fita.

HC - ... Quem implantou esse serviço lá dentro foi o Osório César que era um psiquiatra muito ligado às artes, tanto que ele tinha vivido algum ano, não sei quanto tempo, com a

Revista Digital do LAV - Santa Maria - vol. 11, n. 2, p. 309 - 341 - mai./ago. 2018 ISSN 1983 - 7348 http://dx.doi.org/10.5902/1983734832833512 
Tarsila do Amaral. Ele foi companheiro da Tarsila pouco depois que ela se separou do Oswald.

CE - Antes do Martins?

HC - Antes do Martins. Tanto que ela viajou com ele para a Rússia. Ele era comunista também, eu não sei se você sabe. Ele era do partido, e era uma pessoa muito atuante no partido, e ele era muito considerado como intelectual, como entendido e crítico de arte; senão me engano ele fazia crítica de arte também. E ele implantou esse serviço não sei em que ano.

CE - Mas a senhora lembra quando a senhora foi?

HC - 1953.

CE - Eu consultei aquela tese da Professora Heloísa de Toledo Ferraz, sobre lá, mas não consta a senhora. Ela fez um levantamento de todo mundo.

HC - Ela não fala da Maria Leontina?

CE - Maria Leontina sim.

HC - Maria Leontina tinha me precedido imediatamente; a Leontina tinha deixado, em não sei quanto tempo ela ficou lá. Então a organização da sala, já tinha sido feita por outros educadores. A Maria Leontina, que eu saiba nunca lecionou Arte, eu nunca soube que ela tivesse lecionado. Eu a conheci só como pintora, e com essa passagem de orientação pelo psiquiátrico. A sala era uma sala de uns cinco metros, por sete, parece. Tinha uma mesa oval furada no meio, com lugar suficiente de um metro para eles trabalharem. E eles tinham material já disposto, já organizado quando eles chegavam, cada um tinha o seu lugar e eles gostavam de lugar fixo. E só havia dois doentes que não tinham lugar fixo. Uma era uma japonesa, que desenhava muito bem, a moda tradicional, daquelas gravuras japonesas, tinha uns traços lindos, soltos, e ela fazia as mulheres japonesas com os coques, pentes, com quimono. Ela fazia um desenho lindo. Já tinha dado a ela, algum orientador que chegou antes de mim, já tinha dado a ela um cavalete e uma tela vertical onde ela desenhava. E ela não aceitava nenhuma sugestão e nem conversar comigo. E nem com os outros pacientes, nem com os enfermeiros. Aliás, um não conversava com o outro. Eu nunca vi uma conversa, durante um ano que estive lá, nunca vi uma conversa de um doente com o outro. Agora se eu desse atenção, eles falavam comigo, outros não falavam. Eu às vezes questionava uma coisa ou perguntava, dava uma orientação, sobre

Revista Digital do LAV - Santa Maria - vol. 11, n. 2, p. 309 - 341 - mai./ago. 2018 ISSN 1983 - 7348 http://dx.doi.org/10.5902/1983734832833512 
o que eles estavam fazendo discretamente; a maioria, quando não tinha problema e eles estavam fazendo o trabalho corretamente, eu não falava nada. Eu apenas dava atenção, via o trabalho de cada um, e estava à disposição para que eles me perguntassem o que eles quisessem. Mas eu não sabia até que ponto eu podia interferir. E as conversas que eu tinha com eles, às vezes se mostravam contraproducentes. Eu me lembro do caso de uma doente, que me perguntou, conversando comigo, se ela não teria o direito de visitar o filho dela, numa fazenda ali do lado do Juqueri, que eles não deixavam, que a direção não deixava, que os guardas não deixavam, a senhora não acha que eu poderia fazer? Eu disse é, acho que poderia, pensando que era uma conversa sem consequências. Entretanto, ela tentou realmente ir para a Fazenda dela, foi presa no caminho ficou de castigo, durante dois meses ela não frequentou e eu fiquei muito arrependida. Agora eu poderia ter dito, queria ter tido uma orientação quando eu cheguei lá. Eu deveria ter pedido. Como eles não me ofereceram eu não me aproximei de ninguém. Porque ninguém dava muita atenção, ninguém nunca me perguntou o que eu precisava, o que eu queria, ou o que ... nada, nada, nada. Apenas, eu solicitei uma vez de ir numa condução, num trem, meia hora depois, e sair meia hora também, depois do horário. Eu devia chegar lá às $9 h$ e sair às 11h. Eu pedi para chegar às 9 h30min e sair às $11 \mathrm{~h} 30 \mathrm{~min}$ para eu pegar o trem mais rápido que o trem que eu ia, indicado por eles para eu ir, para chegar as nove era um trem que ia parando e demorava muito. Aí eles me concederam. Logo, um tempo depois, eles objetaram que isso perturbava, porque eu não chegava na hora em que os doentes chegavam na sala. Mas, eu disse que não, que eu só podia ir naquele horário, e eles concordaram. Foi a única vez que eu tive necessidade de ir à secretaria para pedir alguma coisa. Quando eu me sentia mal lá dentro, eu ia ao médico que tinha do lado ali. E os doentes também iam. Os que se sentiam mal pediam para ir ao médico; tinha médico na salinha do lado dali. Quando, uma vez ele me deu um calmante muito forte, eu dormi em pé. E eu fui procurar esse médico por indicação de uma das pacientes, e ela também tinha ficado nervosa, porque ela me viu chorando. Não sei porque, às vezes eu tinha vontade de chorar de ver aquelas pessoas ali, sabe, comovia. Eles eram muito passivos, eles eram muito tranquilos, e eles faziam queixas muito dolorosas para a gente ouvir.

CE - Eles estavam provavelmente medicados.

HC - Ah, medicados sim. E elas só me mandavam gente que estava num estágio de poder ter concentração para trabalhar, de não serem agressivos, evidentemente. Eram pessoas que tinham coordenação motora e que tinham certa tranquilidade. Aparente tranquilidade total. Agora, às vezes, no meio de uma conversa, uma pessoa começava a falar coisas desconexas. Isso me assustava um pouco, porque eu não sabia, se aquela conversa que ela estava tendo comigo tinha provocado algum tipo de emoção, que levou aquilo. Uma 
vez ela começou a conversar dos filhos, da família dela, e daí de repente ela desandou. Então, eu sentia que faltava para mim, certa estrutura, para poder conduzir aquilo de um modo sem agredir os doentes.

CE - Faltou orientação, não é?

HC - Faltou. E estudo, não é? E estudo de minha parte para poder assumir. Mas como essas coisas são mais ou menos improvisadas, ou você encontra uma pessoa que queria ir, ou não tem nada, então eu aceitei, concordaram.

CE - Agora, eles usavam a Arte como uma terapia que pudesse ajudá-los a se curar?

HC - Eu não sei como era que era feita a seleção para levá-los para lá. Provavelmente eles tinham um estudo do paciente e achavam que ele trabalhando com Arte, teria um benefício. Eu nunca conversei com ninguém sobre aquilo. Eu ia assim como um robô, que ia monitorar aquela aula, como uma máquina, que era preciso fazer aquilo. Alguém tinha organizado e dirigido, e pediu para que eu tocasse aquilo num modo que eu tinha prática de lidar com criança e com a Arte. Com aquelas técnicas comuns que se podia dar lá. Que era praticamente pincel e tinha um pouco de barro. Mas a maioria não gostava de barro. Só tinham desenho e pintura, e cada um tinha as suas características. Havia um, por exemplo, um homem muito tranquilo, de uns 30 anos, ele tinha vindo do campo, e ele só desenhava fazendas com vacas e bois. As vacas ele colocava de um lado e os bois dos outros, separados por uma grade. Era a situação dele ali dentro do sanatório. Tinha a parte feminina e a parte masculina. Então ele desenhava assim muitas vaquinhas, muitas vaquinhas, era minucioso, era um desenho mais ou menos como um primitivo, mas um primitivo bem feito. Muito cuidado, miudinho. Tinha duas pessoas que tinham um trabalho muito bonito: era o desse rapaz e o da japonesa. Teve a japonesa, que teve aquele episódio que eu te contei; a única pessoa que gostava de barro, era uma mudinha, que só fazia barro, não gostava da pintura. E ela gostava muito do barro. Ela fazia bichinhos, as figurinhas, mas ela não sabia colar o barro, ela fazia as partes e não sabia colar o braço na parte do corpo, mas ela não conseguia se concentrar direito, para fazer, então no dia seguinte estava tudo desmembrado, as partes se desmembravam. E ela achava que era a japonesa, que era muito brava. Ela punha a culpa na japonesa. Ela falava comigo, mostrava o trabalho, como era muda, ela mostrava o trabalho, dizia que estava quebrado e dizia que era a japonesa. E que ela ia bater na japonesa, e um dia, sem mais nem menos, já fazia um tempo que eu estava lá, então os enfermeiros já relaxavam um pouco, então num determinado momento, saiu todo mundo da sala, eram três enfermeiros, normalmente. Às vezes ficavam só dois, às vezes ficava um, e nessa hora, não tinha

Revista Digital do LAV - Santa Maria - vol. 11, n. 2, p. 309 - 341 - mai./ago. 2018 ISSN 1983 - 7348 http://dx.doi.org/10.5902/1983734832833512 
nenhum na sala. Mas eu só me dei conta disso quando a mudinha pegou a comida vinha para eles ali, tinha um panelão grande de comida, eles serviam um prato cada um, e eles comiam no lugar em que eles estavam, onde desenhavam. E a mudinha ficava em pé, ela não gostava de sentar, ela então ficava ali passeando pela sala, e a japonesa ficava quieta no seu canto, no seu cavalete em geral, olhando para a parede. Nessa hora ela estava meio de lado, a japonesa estava meio de lado, com a cara bem redonda, chatinha assim, não é, com bastante espaço para ser jogado um punhado de comida; de peixe misturado com arroz. Ela pegou aquele punhado e jogou. De um canto da sala para outro, ela jogou uns seis metros, aquela comida com toda a força que bateu na cara da japonesa que era redonda e chata, a japonesa que era tão brava que não deixava nem eu chegar perto do desenho dela, quando eu chegava para ver o desenho dela, ela largava o desenho e ia olhar para a parede, ficava bem perto da parede, até eu me afastar, aí ela voltava para o lugar, ela não precisava de orientação, porque eu realmente não poderia dar orientação para ela, porque o desenho dela era mais bonito do que qualquer coisa que eu pudesse orientar a ela. E a japonesa simplesmente pegou a mão assim, tirou a comida do rosto, não ficou brava e nem falou nada. Eu fiquei apavorada. Quando eu vi a mudinha fazer isso, eu olhei para os lados, não vi um guarda, eu disse: estou frita! Porque essa japonesa vai revidar, vai sair uma briga, eu não sabia a reação que isso ia provocar nos outros doentes, se eles iam entrar também, mas não aconteceu nada. Bom, nunca havia nenhum outro incidente, eles trabalhavam tranquilamente do começo ao fim da aula, havia trabalhos interessantes. Mas não muito. Nunca tive trabalhos como a Nise da Silveira fez lá no Rio de Janeiro. E ela tinha um acervo grande de trabalhos, e aí eles estudavam, porque lá era um trabalho integrado, do trabalho de Arte com a parte psiquiátrica, dos médicos. Então, eles analisavam, e eles têm um acervo lindíssimo. Trabalhos muito bons. Aqui, no tempo em que eu estive, eu não achei nada de muito interessante. Às vezes a gente dava aquele processo de estimular através de um objeto ou outro, mas a maioria das pessoas não gostava, gostavam de produzir aquilo que eles tinham dentro da cabeça.

CE - Alguns deles perguntavam alguma coisa para a senhora, ou pediam ajuda?

HC - Eu não me lembro de ninguém pedir ajuda para nada lá, só a mudinha é que tentava que eu ensinasse alguma coisa de modelagem, e de pintura, eu não me lembro de ninguém nunca ter me perguntado nada.

CE - E como a senhora ficava no trabalho?

HC - Em ficava em pé o tempo inteirinho, as duas horas eu ficava atenta. Agora, eu não sei o que eu fazia, não lembro. Não lembro qual era a atitude que eu tomava, eu penso 
que quando eu via alguma coisa que tivesse algo demais, acredito, porque eu não sei o que eu fazia, durante duas horas, alguma coisa eu devia fazer. Eu não ia ficar parada olhando.

CE - E era todo o dia?

HC - Não, não eram duas vezes por semana.

CE - Duas horas, duas vezes por semana, então seriam quatro horas por semana?

HC - Eles ficavam mais de duas horas. Tanto que eu pedi para chegar mais tarde, porque eles chegavam, lembro um dia em que eu cheguei mais cedo, e eles já estavam lá. Eles ficavam umas quatro horas lá.

CE - Mesmo sem a sua presença?

HC - Mesmo sem eu estar lá, eles já estavam trabalhando. Agora para uma moça que estava lá, que era com quem eu mais conversava, ela se comunicava comigo, parecia mais lúcida do que os outros, eu perguntei se ela gostava de estar lá, porque você gosta de pintar? Não, é por que aqui a comida é melhor. Eu venho para aqui, porque aqui eu tenho uma comida melhor. Os outros nunca me falaram porque gostavam. Também eu acho que eu não tinha muita comunicação com eles. Eu tinha também um pouquinho de medo e eu não sabia como abordar.

CE - E eram tanto homens como mulheres, ou eram mais mulheres?

HC - Tinha mais mulheres. Mas tinha homens também. Eu também não lembro a quantidade de alunos, mas provavelmente entre 18 e 20. Eu já encontrava todos sentados, quando chegava já com o seu material, era uma daquelas enfermeiras que distribuía. $A$ tinta era como aquela que eu tinha também, aquela tinta feita com pó de pintor, pincéis com água. Aquela mesma organização que tínhamos lá na Escolinha de Arte.

CE - Mas isso, quando a senhora chegou lá, já era assim?

HC - Já era assim.

CE - Essa forma de organizar era uma forma corrente na época?

HC - Eu não conhecia muito. Não havia também. Aqui tinha, a Fanny, que foi antes de mim, antes de eu ter a minha escola, quando eu entrei na Fundação, ainda a Fanny não 
estava trabalhando. Ela trabalhava numa Escola Israelita, lá no Bom Retiro, ela já fazia Artes lá. Nunca visitei, não sei como era.

CE - E porque a senhora resolveu sair de lá?

HC - Eu pedi para sair. Eu acho que era muito trabalho. Eu não tinha mais tempo. Deixame lembrar um pouquinho em que ano eu saí; e porque eu saí.

CE - Isso foi quando a senhora foi para o Clubinho infantil ou depois?

HC - Não, não foi, porque o clubinho era só aos sábados à tarde. Eu acho que foi porque eu estava cansada de viajar, sabe. No Clube Infantil eu devo ter entrado mais ou menos em 1954, em 1955 passou para a FAAP. Ah, foi por isso, nós passamos para a FAAP e aí eu comecei a dar mais aulas lá na Fundação, porque não havia professores, a FAAP estava recém-formada, o prédio ainda inacabado e vieram do Museu, e não havia muitos professores, tanto que eles me deram o Curso de Adultos para eu trabalhar à noite, eu fiquei com o Curso de Adultos. Havia talvez outros professores, mas poucos. Logo depois começaram a entrar. A Renina entrou. O Nelson Nóbrega, se lembra de um rapaz que pintava umas pinturas mais acadêmicas, que era genro do Monteiro Lobato, que era pintor? Ele trabalhou lá na FAAP, e começou a trabalhar um pouquinho depois que eu entrei lá, e ele pegou muitas aulas, essas aulas da noite, depois passaram para ele.

CE - A senhora tinha aulas na FAAP eram só a tarde, ou eram de manhã e à tarde?

HC - Bom aquilo foi aumentando, não é? Logo que eu cheguei tinha apenas à tarde. Depois foram havendo procuras para durante a semana, então nós começamos, gradativamente, a aumentar as aulas para durante a semana, e aí nós abrimos logo para duas vezes por semana à tarde, duas vezes por semana de manhã, depois aos sábados sempre continuou. Depois de sábado passou para de manhã. Durante a semana, depois foram aumentando as classes porque quando eu saí de lá em 1970, eu estava ali desde 1965, entre jovens (infantil e juvenil). O curso para jovem quem começou a dar aulas lá, foi o Eduardo Sued, que trabalhou muitos anos lá. Depois que ele saiu, foi para o Rio de Janeiro, quem ficou foi a Fernanda Milani, que trabalhava como assistente minha na classe. Quase todas as professoras começaram a trabalhar como assistente minha, depois que a gente foi desmembrando as aulas, as classes, elas passaram a ser autônoma.

CE - D. Hebe, a senhora dava cursinhos para professores? A senhora diria que chegou a dar cursinho para professores?

Revista Digital do LAV - Santa Maria - vol. 11, n. 2, p. 309 - 341 - mai./ago. 2018 ISSN 1983 - 7348 http://dx.doi.org/10.5902/1983734832833512 
HC - Muitos.

CE - A senhora então acabou tendo uma atividade parecida, vamos dizer assim, com a Escolinha de Artes do Brasil, porque muitos eram seus alunos, tornaram-se seus ajudantes e depois se tornaram professores

HC - A única coisa que eu sempre enfatizei foi o professor como agente, ele não era quem já deviria ter, elas foram formadas para isso, não é? E como transmitir? Então, tinha que ter esse curso, conhecer a criança através da psicologia, através de outros métodos, para saber o que é que se podia dar, para que idade. Porque isso é muito importante. Porque você não pode exigir de uma criança de quatro anos que te desenhe a figura humana completa. Ela tem o seu esquema que é universal, porque isso depende do desenvolvimento mental da criança. Mental, motor, da sua visão de mundo. Mental é psicológico, não é? Senão você não teria um esquema universal da criança. Então, você precisa ter esses conhecimentos. Eu achava que isso era óbvio. Então que eu sempre enfatizei, que o professor de Artes tem que ter, além dessa preparação de saber transmitir, que não é todo o artista, todo o pintor que sabe a técnica corretamente, tem que ter vocação habilidade e conhecimento. Ou então, eu já vi muitas pessoas, com muito conhecimento, que na hora de transmitir para a criança, não sabe como conseguir, como transmitir. Então, eu sempre enfatizei isso, a maneira de você transmitir as técnicas, a que horas, em que momento, com que idade a criança pode usar tal técnica, e à medida que ela vai crescendo você tem aí que nem que você vai coibindo um pouco a criança, você tem que ensinar alguma coisa. Porque senão ela se desinteressa, se ela não souber que ela está aprendendo, ela não quer fazer um desenho livre, senão ela chega nos 11 a 13 anos é uma parte muito difícil, porque ela começa a ficar insegura, ela já não tem aquele desenho espontâneo, ela já é mais crítica, ela passa a não ter confiança no desenho dela, embora seja maravilhoso, ela precisa entrar no figurativo e saber copiar alguma coisa, a não ser que ela tinha tido aulas desde muito cedo, como no caso do Grupo Escolar Experimental, onde as crianças começavam a trabalhar com cinco anos, com sete anos de formação, ou quando tinha quinto ano, com onze ou doze anos. Quando eu cheguei no Experimental, eu tinha crianças de quatorze ou quinze anos, eram repetentes. Foi terrível, porque eles nunca tinham tido aulas de Artes. Então, eles não sabiam o que fazer com as mãos. Eles não tinham absolutamente confiança no que eles faziam, e eles só queriam fazer desordem e bagunça. O primeiro ano foi terrível lá no Experimental. Agora aquele que tinha começado cedo, você vê que ele tinha confiança no trabalho dele. Ele já não precisava mais de você dar esse suporte. Agora, se você tem uma criança durante muitos anos, ele tem que sentir que ele evolui em alguma coisa, ele não tem parâmetro, então a

Revista Digital do LAV - Santa Maria - vol. 11, n. 2, p. 309 - 341 - mai./ago. 2018 ISSN 1983 - 7348 http://dx.doi.org/10.5902/1983734832833512 
evolução se dá no campo da Arte figurativa. Mas ele tem que saber copiar, então você tem que ensiná-lo a ver, a fazer perspectiva linear, porque ele não acredita na arte pura.

(fim da fita)

CE - Era Grupo Escolar Ginásio Pluricurricular Experimental "Doutor Edmundo de Carvalho"?

HC - Eu visitei o Ginásio uma vez, mas eu trabalhei uma vez quando eu ainda trabalhava na Fundação, trabalhei no Santa Maria, não lembro se ainda estava no Experimental, não lembro. Eu trabalhei no Santa Maria, era um colégio canadense, eles tinham uma sala linda, tinham umas pias enormes, aqui em São Paulo, no Brooklin, lá em cima depois da Chácara Flora. Eles iam me buscar de ônibus, me pegavam, pegavam os alunos, e eu ia para lá. Eu não tinha muito interesse porque eram adolescentes de treze ou quatorze anos, e eles tinham assim, por exemplo, festividades religiosas e havia uma procissão interna, era uma data qualquer religiosa, eram freiras, freiras canadenses, era muito interessante, a diretora falava muito bem português, tinha estudado com a minha irmã. Minha irmã lecionava português no Instituto Brasil - Estados Unidos em Washington. Tinham freiras brasileiras também. E eu no momento de fazer uma procissão eu comprei papel colorido grande, aquele papel crepom, e mandei fazer recortes de símbolos da igreja, e fizeram bandeirolas grandes, de 1,30 a 2,00 metros, e elas fizeram a procissão carregando os estandartes. Ficou lindo. O professor tem que ter maleabilidade e adaptabilidade ao ambiente, e aos recursos que ele tem. Ao ambiente, ao interesse do grupo que você vai trabalhar. Você tem que satisfazer a quem está empregando, para quem você está trabalhando, e ir tornando possível você realizar o trabalho, não é que você queira bajular quem está te empregando, você tem que satisfazer para você poder trabalhar. Seja porque você precisa daquele honorário que você vai receber, seja por interesse de realização pessoal de fazer alguma coisa, seja porque for, você precisa ser o suporte, então você precisa saber agradar. Eu, por exemplo, nunca tive tanto apoio como tive da Therezinha Fram no Experimental. Durante os cinco anos que eu estive lá, nunca ela disse: "Hebe, podemos fazer isso, no lugar disso?" Mas com a Diva nunca me entendi bem, agora Therezinha foi de uma delicadeza, compreensão, de uma confiança, ela depositava uma confiança em mim extraordinária. Flávio Motta, lá na Fundação também. Eu sempre chegava atrasada.

CE - Ele dava bronca?

HC - Ele brincava. Ele me encontrava chegando meio atrasada, mas como não me lembro muito, como eu delegava muito, pois eu colocava o bedel, o faxineiro para me ajudar na 
sala (risos), para cortar o papel, para distribuir o papel, e eles já sabiam que era só deixar as crianças trabalharem. E as crianças já estavam acostumadas, chegavam e iam trabalhando e pronto! Quando eu chegava era só dar continuidade. Eu nunca tive planejamento prévio de aulas. Os alunos chegavam loucos para botar no papel aquilo que eles tinham na cabeça. Então não havia necessidade. Você dando o material, a criança que está acostumada a uma disciplina, trabalha. Tinha um ou outro aluno danado, como o Célio, mas que não perturbava o resto da classe, porque ninguém topava. Ele fazia a bagunça dele, no canto dele. Criança é toda igual. A cara é igual, o jeito é igual.

CE - E a história de jogar barro no teto? (risos).

HC - É, por isso que eu quis sair daquela sala tão grande, porque estimula, porque a criança ela quer dominar aquele espaço todo. Então, como é que ela vai dominar àquela altura? É jogando para cima, não é? O Célio não perturbava muito os outros não, não perturbava muito. A mim, me perturbava muito, porque eu gostava de disciplina.

CE - A senhora sabe que eu me lembro uma única vez de ter visto à senhora brava. Eu me lembro, lá no Experimental, que devia ser quarto ou quinto ano, que eles chamavam de quarto ano complementar, que era uma turma de "repetentes". Eu lembro que a senhora ia trabalhar, lembro que a senhora tinha pedido na aula anterior, que também era isso, com aquele rolinho de papelão do fundo do papel higiênico, se enrolou barbante, ai pincelava-se com tinta, e rolava sobre o papel. Trabalhava-se estampagem, no papel. E eu me lembro que entrou essa turma, e a senhora falou: então hoje nós vamos fazer uma combinação. Aí virou uma menina e falou: então precisa tecido, agulha, tesoura e linha. Aí a senhora ficou tão brava! E a senhora disse: mas você é muito petulante, não é menina? Porque ela foi agressiva, ela não falou numa boa, ela quis fazer ironia, e a senhora percebeu isso. E eu lembro que ela aí se segurou.

HC - Eu sempre achei que você tem que dar o seu tom. Você tem que ser benevolente, compreensivo, tem que ser dócil, mas você tem que ser enérgico na hora que a pessoa faz a primeira vez. Se você deixar fazer a primeira vez e não tomar uma atitude, nunca mais você consegue. Você cortando na primeira vez, você tem que dar o seu tom, você tem que dizer para que você veio e o que você espera dos alunos. Que você é então uma autoridade na sala, e eles têm que fazer aquilo que você quer. Não pode questionar muito.

CE - Caso contrário, você perde toda a condução do processo, não é?

HC - Claro que você perde, pode ser que eu tenha errado muitas vezes. Você sabe que eu cheguei uma vez a dar uma palmada num aluno? (vide entrevista Célio Bernardes, p. 56). 
CE - Isso eu não sabia (risos).

HC - Não sabia. Mas acontece o seguinte, eu sabia em que eu estava dando a palmada. Em primeiro lugar, era um aluno que eu tinha visto dentro da barriga da mãe dele, porque ele estava na barriga da mãe, e eu já estava ensinando as filhas dela. E ela continuou na Fundação, depois ela trouxe os filhos para estudarem na minha escola. Esse aluno foi igual, tipo Célio, só que o Célio era mais brincalhão, o Célio era aquele jeitão dele, sempre alegre, sempre bem-humorado, e esse era meio psicótico, ele ficava a aula inteirinha debaixo da mesa. E eu dizia: você vai sair daí, taquei-Ihe uma palmada na mão, aí ele saiu e nunca mais entrou. Tem umas horas que uma palmadinha não faz mal. Agora, professor não pode fazer isso, porque senão ele vai para o Conselho Administrativo, e é expulso da Escola. Agora, lá era a minha Escola particular, o máximo que a mãe podia fazer era tirar ele da Escola. Mas eu sabia que o aluno não ia nem ter coragem de dizer para a mãe dele que eu bati nele. E se dissesse, também, a mãe não ia se incomodar. Ela é minha amiga até hoje. Ela e o marido. Então, eu podia fazer. Agora não era como na Escola Alemã, que eu me lembro. Eu morava em Campinas e vim aqui para São Paulo, eu não era ainda alfabetizada, eu frequentava a escola lá, mas eu não era alfabetizada, com sete anos. $E$ eu entrei numa Escola Alemã. Isso eu era um pouco alfabetizada, eu sabia ler muito mal. Colocaram-me numa Escola Alemã, que era aí na Praça Roosevelt. Aquele prédio ainda existe.

CE - É o Caetano de Campos de antigamente, que foi dividido em dois, uma parte foi para a Aclimação, e outra parte para a Roosevelt, no prédio que era da Escola Alemã Porto Seguro. E o prédio que era do Caetano virou Secretaria da Educação.

HC - Então ali no Porto Seguro tinha um jardim lindo, que a gente brincava. Uma vez, chegando na classe, tinha uma porção de alunos na minha frente. O professor manda puxar um livro que ele tinha dado, em alemão, e mandou ler. Eu não sabia ler em português, vou ler em alemão? E mandou os alunos lerem. O primeiro leu, o segundo leu, o terceiro foi ler, e leu errado e ele pá, uma bolachona na cara do menino. É difícil dar na cara, porque brasileiro não costuma dar na cara. Bom, eu fiquei apavorada. Eu pensei se esse aluno que sabe ler, que sabe alemão, que errou alguma coisa, o que é que este senhor professor não vai fazer comigo? Eu fui ficando apavorada. Aos poucos, eu aprendi que ele só batia em alemão. Bater em brasileiros pegava mal para ele, não é? Então eu fiquei lá.

CE - E tem mais alguma coisa que a senhora gostaria de falar D. Hebe?

HC - Deixa-me ver se eu lembro alguma coisa. Sobre esses cursos de formação de professores, a minha pretensão não era impor o princípio, o dogma, claro. Uma central 
que todo mundo tivesse que recorrer àquela central, que foi o caso da Escolinha do Brasil. O Augusto Rodrigues chegou a conseguir leis, que o professor não podia ensinar Arte se ele não tivesse cursado o curso Infantil no Rio de Janeiro. Então, o meu curso não abrangia psicologia, era apenas um curso técnico. Que nós fizemos, deixa-me ver se o fiz em São Paulo.

CE - A Paula Motta em sua entrevista conta que na sua Escolinha a senhora chegou a ministrar cursos de treinamento para professores. E ela conta que numa época ela trabalhava com a senhora e foi fazer um curso ou estágio com a Fanny Abramovich. Ela conta as diferenças entre o seu método e os da Fanny.

HC - É ela me contou que a Fanny deixava as crianças trabalharem com fogo. E um dia eu pego a Paula, parada, olhando para uma criança sentadinha no chão, no jardim, pegou o pintinho dele, e estava tentando enfiar um prego e bater com o martelo no pintinho. $E$ a Paula olhando, dizendo: "Não pode fazer isso".

(fim da fita)

HC - Eu vou mostrar a você.... Uma vez eu fui à secretaria, que é ministério. O ministro da Educação foi na organização da exposição, e essa exposição, depois correu diversas escolas do Estado. Então eu fui convidada, para visitar as escolas, a abertura da exposição. Mas tudo assim, eu fazia, mas não chegava a uma conclusão.

CE - Eu acho que a senhora podia não ter uma conclusão teórica, mas eu acho que a senhora jogava isso na sua experiência do dia a dia.

HC - Então, como eu disse a você, eu morava lá, por isso que eu tive essa oportunidade, de fazer, porque a minha irmã frequentava a embaixada.... Então ela (inaudível) ... Mesmo minha família morando lá, eu ia às férias, mas eu vinha para estar no primeiro dia de aula, na escola. No primeiro dia de aula, eu achava importante a professora estar. Eu levava muito a sério, durante vinte anos trabalhando cotidianamente. Eu formei muita gente. Eu formei um bedel lá na Fundação, ele limpava as salas. Eu ensinei a fazer tinta, a guardar os trabalhos dos alunos, ele era brilhante. Ele estava sempre presente no início e no final das aulas. Quando eu chegava na sala eu já encontrava toda essa organização. Ele colocava o papel, já fazia e colocava a tinta, e se eu chegava atrasada, ele ia começando as aulas.

CE - Ele e a Malvina então, não é?

Revista Digital do LAV - Santa Maria - vol. 11, n. 2, p. 309 - 341 - mai./ago. 2018 ISSN 1983 - 7348 http://dx.doi.org/10.5902/1983734832833512 
HC - Sim, você não sabe como eu tenho saudades dele. Ele está vivo ainda, mas ele está aposentado. Não sei dele, a última vez que eu o vi, foi numa exposição que eu fiz aí no Pacaembu, e ele foi. Ele ainda trabalhava na Fundação. Em 82, há vinte anos. Ele era perfeito. Ele se chamava Antônio. Eu mandei um convite da exposição para ele, e foram dois bedéis lá. Agora ele que era o que gostava e que se aprimorou. Depois eu saí de lá. Porque os alunos pagavam, e tinha uma carteirinha. Todo mundo pagava, que eu saiba nunca ninguém deixou de pagar, mas eles começaram a exigir, que a criança não entrasse mais em aula, sem estar com o recibo na mão. Eu lá dentro, chegou um menino que não tinha o recibo, não tinha pagado, ele teve ordem da diretoria do curso, para não ficar. Eu acho que foi de ... essa ordem de mandar o aluno embora. Agora o aluno de sete anos chegou na classe e não deixaram entrar, mandaram o menino para casa, um menino de sete anos voltando sozinho para casa, o pai ia levar e buscar, mandaram embora. Logo depois, eles fecharam o infantil, alegando que dava muito prejuízo, mas aquilo foi criado sem fim lucrativo, e eles tomaram conta daquilo. Eles dominaram a Álvares Penteado. (...) Como eu disse a você, não acho que exposições de arte sejam para crianças de três, quatro anos, mas, eu acho que dos oito anos em diante. (...) Mas sabe, você falando da Tarsila, eu lembrei de um detalhe do tempo em que ela viveu com o Osório César, eles eram muito amigos do Theodoro Braga. Então muitas vezes eles à noite, quando a gente estava tendo aula ali, eu via a Tarsila lá com o Osório. Entretanto, embora ela fosse Modernista, ela era muito amiga do Theodoro Braga. Mas ele não gostava do Modernismo, e nem queria que nós víssemos. Ele nunca incentivou isso. Mas era muito amigo pessoal deles dois.

\section{CE - E o Flávio de Carvalho, a senhora conheceu?}

HC - Conheci. O Flávio era uma pessoa assim muito, de convívio, era uma pessoa muito gentil, recebia muito, na casa dele, e tinha um gosto muito sofisticado. Mas as pessoas tinham sempre uma certa resistência. Sempre críticas, sempre o levavam muito na brincadeira. Tinha um artigo muito interessante do Sérgio Milliet sobre ele. Eu não tenho mais. Dizendo que não havia muito que contar dele, ele estava fazendo um artigo de contar, e ele mesmo já contou tudo sobre ele mesmo. Mas ele era uma pessoa muito culta, que levava muito a sério o seu trabalho, e que ele era muito acima de qualquer piada. Ele não era levado muito a sério, como não era levado muito a sério, aqui em São Paulo, nenhum artista que tivesse um pouco mais de dinheiro do que o normal. Não é que o Flávio fosse muito rico. Ele tinha uma fazenda, tinha alguns recursos, mas ele nunca fez um trabalho regular. O Flávio fazia muitas experiências, o trabalho dele mesmo como arquiteto, ele nunca foi levado a sério. Então, ninguém encomendava trabalhos para ele. Ele construía para ele. Construiu aquela série da Alameda Lorena, que ainda tem umas remanescentes, uma ou duas que são autênticas, como era antes, mas a maioria reformou. 
Então, ele fez uma série de casas ali para alugar, e ele fez a casa dele na fazenda, fez diversos concursos, mas nenhum foi executado. Ele fez um projeto para o Palácio do Governo de São Paulo. Ele participou de um concurso, mas também não venceu. Ele fez um projeto para a Assembleia, só de vidro e estrutura de ferro, como hoje se fazem os prédios modernos, isso há sessenta anos. Ele tinha uma modernidade muito grande. Mas, ele não sabia trabalhar em equipe, ele não sabia se organizar economicamente, então o trabalho dele ficou meio disperso. Mas ele era um grande desenhista. Ele era muito amigo das minhas tias lá de Recife. Desde muito mocinho, ele e os amigos dele, muito amigos das minhas tias, sempre muito polêmico. Ele era muito baixinho, e minhas tias eram bem altas.

HC - Você conheceu o Sérgio Milliet?

CE - Não.

HC - Sérgio Milliet era um escritor que era muito interessante, pessoalmente ele não estava tão bem, porque ele bebia muito. Sabe, eu acho que o álcool vai comendo muito os neurônios, e ele já não era aquele homem brilhante, ele escrevia bem, mas para o papo ele já não era bom.

\section{(...)}

HC - A Ana Mae uma vez reuniu diversas pessoas para focalizar determinadas orientações de arte lá na Cidade Universitária. Então ela disse: eu queria que você fosse Hebe, e levasse pessoas, que pudessem dizer algo, dentro daquele espírito que elas foram formadas, trabalhando com você. Vai ser tal dia, eu vou te dar duas horas, não é fácil. Você leva o que você tiver, você leva vídeos. Eu falei com as pessoas. Quando eu chego lá, eu encontro Ana Mae na sua sala com o Maurício Segall, para falar do trabalho infantil que eles faziam lá no Museu. Então, quando chegou à hora de começar, ele disse começa a senhora. Eu tinha preparado duas horas de palestra. Ele teve que me esperar muito. Ninguém tinha me avisado que ia ter outra pessoa, que ia ocupar aquelas duas horas também. Então eu tentei dar a coisa corrida de minha parte, para não ocupar tempo, porque eu vi que não ia dar. E todas as pessoas que eu levei diziam: - Bom, eu fui aluna da D. Hebe, fiz isso, fiz aquilo... Depois chegava outro: - Eu fui aluno de D. Hebe... A outra a mesma coisa... Aí, quando ele começou a falar: eu não fui aluno de D. Hebe, mas meu trabalho é esse, estou fazendo lá no Museu, então ele fez aquela ironia. Eu tive vontade de dizer: - Pois é, você não foi aluno da D. Hebe, mas seu filho foi, nessa época você estava preso. A Beatriz Segall, que na época era casada com você, levou o filho de vocês para estudar comigo lá para ele aguentar a prisão que você teve durante a época da 
ditadura, porque ele era comunista, ficou muito tempo. Mas eu fiquei tímida e não falei nada. Mas eu deveria ter falado. "É, pois é, você não foi, mas seu filho foi. A Beatriz levou, porque achou que ele estava precisando dessas aulas, para aguentar" (TRIGUIS, 2007, p. 42-59).

Essas desqualificações masculinas em relação às mulheres profissionais parecem brincadeira, mas minam a nossa autoestima e nos deixam vulneráveis e tímidas. Aqui fica minha homenagem a Hebe Carvalho e a Carlos Triguis.

O feminismo de hoje é construído em parceria com os homens negando a submissão entre seres humanos.

\section{Referências}

PASTORE, M. O segredo dos 101 anos de vida da artista plástica Hebe Carvalho. Catraca Livre. 2017. Disponível em:<https://catracalivre.com.br/geral/cidadania/indicacao/osegredo-dos-101-anos-de-vida-da-artista-plastica-hebe-carvalho/>

TRIGUIS, C. E. De educando a arte-educador: um percurso; influência dos mestres. 2007. 2 v. Dissertação (Mestrado) - Universidade Estadual Paulista, Instituto de Artes, 2007. Disponível em: <http://hdl.handle.net/11449/90994>.

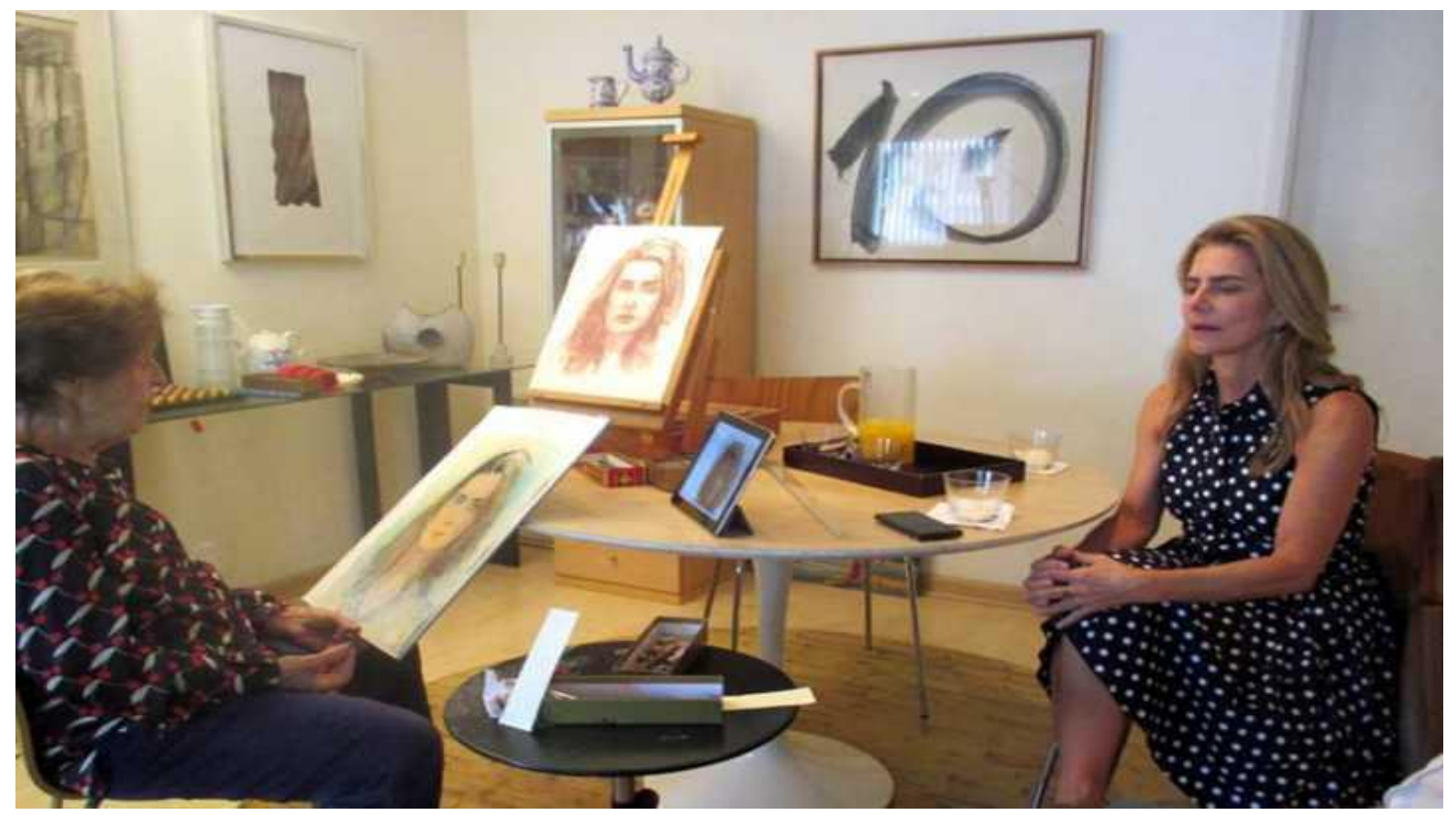

Figura 03. Em 2015, Hebe fez o retrato da atriz Maitê Proença. Créditos: Arquivo de Maria Amélia de Carvalho

Fonte: Catraca Livre 
Possui graduação em Direito - Universidade Federal de Pernambuco (1960), mestrado em Art Education - Southern Connecticut State College (1974) e doutorado em Humanistic Education - Boston University (1978). Atualmente é professora titular aposentada da Universidade de São Paulo e professora da Universidade Anhembi Morumbi. Tem experiência na área de Artes, com ênfase em Arte/Educação, atuando principalmente nos seguintes temas: Ensino da Arte e contextos metodológicos, História do Ensino da Arte e do Desenho, Ensino do Design, Administração de Arte, Interculturalidade, Pedagogia Visual, Estudos de Museus de Arte, Mediação Cultural e Estudos Visuais.

Como citar esse artigo:

BARBOSA, Ana Mae. Hebe de Carvalho: educando os arte/educadores. Revista Digital do LAV, Santa Maria: UFSM, v. 11, n. 2, p. 309-341, mai./ago. 2018. 